
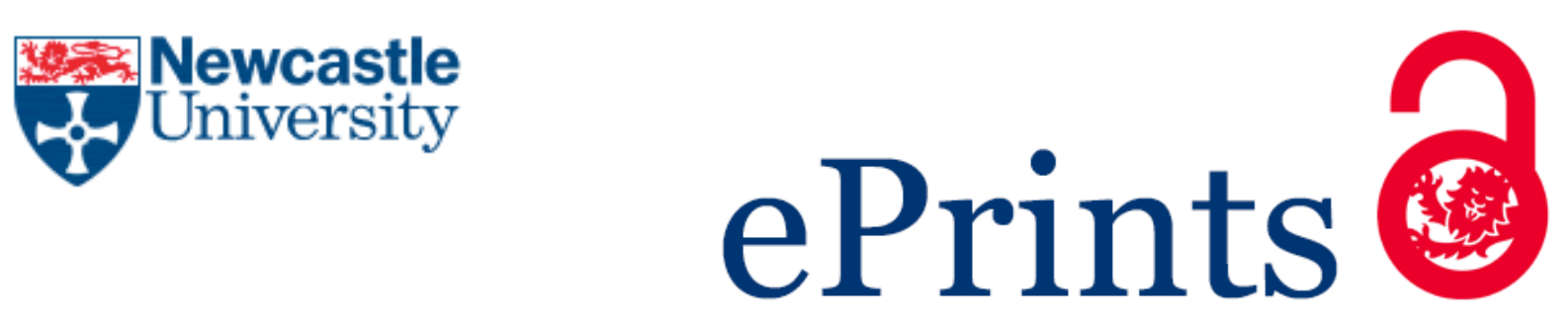

Waltereit R.

Argument structure and argument structure alternations.

In: Dufter A; Stark E, ed. Manual of Romance Morphosyntax and Syntax.

Berlin: De Gruyter Mouton, 2017, pp.154-182.

\title{
Copyright:
}

Copyright 2017 De Gruyter Mouton. This is the authors' accepted manuscript of an article that may be downloaded for personal use only. Any other use requires prior permission of the author and the publisher.

URL link to book chapter:

https://www.degruyter.com/view/product/433693

Date deposited:

$16 / 05 / 2016$

Embargo release date:

01 September 2018 


\section{Richard Waltereit}

\section{Argument structure and argument structure alternations}

Abstract: This chapter discusses argument structure in Romance languages. After a brief review of some of the main issues that current descriptions of argument structure are facing, and of some of the most prominent answers to address these issues (Section 1), I discuss major types of grammatical relations in Romance relevant for argument selection, and the problem of identifying valency of lexical items (Section 2). Section 3 is an excursus about argument structure of nouns and adjectives. Section 4 is devoted to the main descriptive problem of argument structure in Romance (or any language or language family), namely the identification of linking patterns. Section 5 addresses argument alternations. Section 6 is a brief summary.

Keywords: transitivity, valency, argument, semantic role, event structure

\section{What is argument structure?}

Historically, the notion of argument structure is grounded in the recognition that there are no consistent semantic correlates to grammatical relations (in particular, subjects and objects). Consider the following Italian examples, from Salvi (2001, 64-66):

(1) It. Giovanni profuma il suo cane. Giovanni perfumes the his dog 'Giovanni scents his dog.'

(2) It. Il sasso ruppe la finestra. the rock smashed.3sG the window 'The rock smashed the window.'

(3) It. La pietra rotolò giù per il pendio. the stone rolled.3SG down across the slope 'The stone rolled down the slope.'

(4) It. Maria ha sentito cantare Bergonzi. Maria has heard sing.INF Bergonzi 'Maria heard Bergonzi singing.'

(5) It. Il giardino pullula di vespe. the garden abounds of wasps

'The garden abounds with wasps.'

The semantic contribution made by the subject is very different in each of these sentences. In (1), it is an AGENT performing the action of 'scenting'; in (2), it represents the INSTRUMENT of an action which implies an agent; in (3), it has a relatively passive role, often referred to as THEME or OBJECT; in (4), it refers to the EXPERIENCE (as opposed to agency) of a sentient being; and in (5) it refers to a LOCATION. Despite this diversity, the syntax-semantics relationship in verbal arguments is far from arbitrary. An argument with a THEME role can be a subject as in (3), but THEME would also appear to characterize the direct objects il suo cane in (1) and la finestra in (2), and prepositional phrase di vespe in (5). By contrast, in the non-subject arguments there does not seem to be any AGENT; the AGENT role is represented only by a grammatical subject, whether in combination 
with a finite verb in (1) or a non-finite one in (4). Thus, the object is quite variable in its semantic role, though not as much as the subject. Oblique relations, though, i.e. grammatical relations other than subject and object, are less variable in their semantic import.

Thus, the selection of grammatical relations by verbs does not seem to fully determine their semantic contribution; rather, a separate layer of information is involved - argument structure. A number of approaches exist with respect to how this layer of information is organized, and how it interacts with the selection of grammatical relations, and with other components of grammatical information.

The question of how syntactic and semantic layers of predicates interact is, in turn, derivative of a more fundamental property of human language underlying the representation of events. Individual events are expressed by combining an eventtype with a selection of designated participant-types. They reflect an underlying verbal "scene" (cf. Fillmore 1977). The event-types are predicates; their participants are arguments. Prototypically, predicates are verbs, and arguments are nouns or pronouns; but both can be expressed by other word-classes, too (cf. Section 3). In other words, events are normally expressed by articulating several lexical items. This pattern is implied in the very concept of argument structure. Note that such an arrangement, whatever its specifics may be, implies a certain amount of typification and of analysis, where the event is broken down into identified component-types. The choice of predicate implies categorization as a type of event, and the choice of argument implies categorization as a type of participant.

Endeavours to characterize the semantic layer of predicates, and its interaction with the syntactic layer, have led to a number of types of theoretical constructs that address the following questions (Levin/Rappaport Hovav 2005; Croft 2012):

i. Participant roles: How can the inventory of participant roles be characterized?

ii. Event structure: How are events typified in the semantic layer of predicates?

iii. How do participant roles map onto syntactic arguments?

Note that answers to these questions are interlocking, since any attempt to characterize event structure will have an impact on how the participant roles slotting into these event structures are to be defined, and vice versa.

The first approach to argument structure (Fillmore 1968; 1971) conceived of it as selection from a list of semantic argument-types. Many lists have been proposed; other than the argument-types mentioned at the beginning of this section, Fillmore (1971) included COUNTER-AGENT (the force or resistance against which the action is carried out), RESULT (the entity that comes into existence as a result of the action), SOURCE (the place from which something moves), and GOAL (the place to which something moves). Other proposals include, for example, FUNCTION (I used the stick as a club, cf. Comrie/Smith 1977, 29-33), PURPOSE (He made a manger for the church play, cf. Jackendoff 1990, 184), or REPRESENTATION SOURCE (I photocopied the article, cf. Dowty 1991, 569). All lists have in common, though, that they are finite and relatively small (Croft 2012, 180). The list-model addresses the relative semantic indeterminacy of grammatical relations by implicitly assuming an analogy between a finite set of 
grammatical relations and an equally finite set, of comparable size, of semantic argument-types.

One of the main research questions for the list model, then, is the mapping of semantic onto syntactic arguments, i.e. linking. Some of the key difficulties that have beset the debate are that several labels may be applicable to one syntactic argument, and, more importantly, that not always a semantic role-label may be found to be appropriate for a given syntactic argument. Underlying these difficulties is the issue that the role labels were construed as primitives (Croft 2012, 176). An interesting approach to this problem is offered by Koch (1981). He argued that role labels proposed in accounts of argument structure should be conceived of as abstractions over components of individual verb meanings. Koch's model is distinctive in that he derives his role labels from the meaning of pro-verbs (verba vicaria) in the language under consideration, thus avoiding the potential circularity inherent in positing role-labels as primitives that are then used to analyse actual verb meanings. A variant of this line of thought can be seen in the macro-role approach (Van Valin 1999), where lower-level primitive roles are grouped into progressively more abstract higher-level roles. At the most abstract level, there are only two macro-roles: ACTOR and UNDERGOER. Agency, or the lack thereof, is guiding the abstraction process.

A partial alternative to the list-type model of argument structure are theories of event structure. Rather than categorizing events exclusively by the type of participant involved, this approach gives some weight to categorizing events by breaking them up into types of sub-events. This usually takes the form of assuming two tiers of meaning: one containing a small set of primitive predicates, including CAUSE, DO/ACT, BECOME (cf. Jackendoff 1990; Rappaport

Hovav/Levin 1998), and another one containing a larger set of verbal "roots". Combination of elements from the two tiers, via some form of logical calculus, yields actual verb meanings. For example, Spanish romper 'to break' would be decomposed into [[ x ACT] CAUSE [Y BECOME <ROTO>]] (Mateu 2012, 334). ACT, CAUSE, and BECOME are primitive predicates not specific to Spanish, whereas $\langle R O T O\rangle$ would be a Spanish-specific root. Event decomposition puts the linking between syntactic arguments and semantic argument structure on a more principled footing than a mere list approach does, since the semantic arguments of the primitive predicates will have been matched with designated grammatical relations. This matching will be either absolute (for each argument of the primitive predicate a designated grammatical relation, cf. Levin/Rappaport Hovav 2005, 146-147), or relative (allowing for interdependence of designation of grammatical relations, cf. Levin/Rappaport Hovav 2005, 147-152). In any case, though, since the primitive predicates recur across a great number of verbs, the linking procedure should be more consistent than when operating with a list of role-labels only. A potential weakness of this approach, of course, is that the primitive predicates will again need to be posited. Koch (1981) avoids some of these pitfalls by working with constituent predicates that are themselves verbs of the language and can be used as pro-verbs. For example, French demander 'to ask' would contain, at the most general level of its event structure, the constituent verb y avoir 'to occur' 'to exist'; at a slightly less general level the constituent verb se passer 'to happen'; down to more specific demander.

A key reference in contemporary thinking about argument structure continues to be Dowty's (1991) proto-role theory. It is an ingenious combination of the list and the event-structure approach, while avoiding some of either's weaknesses. The key element here is entailment of contributing properties from predicates. 
Contributing properties of event participants are entailed from the predicate; these entailment are then grouped into one of two sets, the AGENT proto-role and the PATIENT proto-role (based on Dowty 1991, 572):

\begin{tabular}{|l|l|}
\hline $\begin{array}{l}\text { Agent proto-role contributing } \\
\text { properties }\end{array}$ & $\begin{array}{l}\text { Patient proto-role contributing } \\
\text { properties }\end{array}$ \\
\hline $\begin{array}{l}\text { volitional involvement in the event or } \\
\text { state }\end{array}$ & undergoes change of state \\
sentience & $\begin{array}{l}\text { incremental theme (affected object } \\
\text { changes proportionally as event } \\
\text { proceeds) } \\
\text { causing an event or change of state in } \\
\text { another participant }\end{array}$ \\
$\begin{array}{l}\text { movement relative to another } \\
\text { participant }\end{array}$ & participant \\
existence independent of event & stationary relative to another \\
& participant \\
& does not exist independently of event \\
\hline
\end{tabular}

Table 1: Agent and patient proto-role contributing properties (Dowty 1991).

A participant with a greater number of agent proto-role properties than with patient proto-role properties will be realized as a subject; in the opposite case it will be realized as an object (Dowty 1991, 576). Thus, there are agent and patient prototypes; crucially, this allows for some variability in subject vs. object realization, and diachronic change, if predicates have an equal number of protoagent and proto-patient properties. We will return to this in Section 4.3. Dowty's model is a major advance over the potentially circular role-list models; and the reference to predicate properties contains an element of event structure, while avoiding the rigidity of the two-tier event decomposition approach. A limitation of Dowty's model, however, is that it applies only to those predicates, and by extension languages under consideration, that have a syntactic subject and a syntactic direct object (Croft 2012, 191).

The growing importance of event structure in analysing the relation between grammatical relations and their semantic contribution (Croft 2012,3) reflects a reversal of perspective. Whereas early research, beginning with Tesnière 1959, tended to be "semasiological" in that it sought generalizations over the semantic import of grammatical relations, researchers are increasingly adopting an "onomasiological" perspective where events are taken as starting point and the linguistic realization of their participants as arguments of predicates (argument selection) is the focus of inquiry.

Du Bois (2003, 27-30) distinguishes distinct components in the overall process of argument selection: inclusion, linking, targeting, and realization. Inclusion specifies which participants of the event will be verbalized in the sentence. Targeting defines the grammatical roles that are available for association with event participants, that is, in the case of verbal predicates, subject, (prepositional) object, and so on. Linking matches, in a general way, function with grammatical relation. Realization spells out the matching of functions with roles for the specific predicate. Du Bois' analytical dissection of argument selection shows that the process applies to the individual event, to the predicate as a lexical unit, as well as to patterns of selection and linking generalized over verbs. The selection process and the relationship between the individual and the patterns of the general level are referred to as argument structure. 


\section{Argument structure and valency in Romance languages}

\subsection{Syntactic expressions of arguments}

A number of form-types (grammatical relations) are relevant for argument structure in Romance languages. Apart from subject (cf. \#\#Chapter II.1) and object, including indirect objects (cf. \#\#Chapter II.2), the following are characteristic for Romance languages.

Commented [ES1]: Editors: Correct format of crossreferencing, here and throughout the whole chapter

\subsubsection{Prepositional objec ts}

"Prepositional object" is a cover term for prepositional phrases that are selected as arguments by their head not by virtue of occupying a designated structural position (cf. \#\#Chapter II.2, Section 2), but by virtue of the head subcategorizing for a preposition. Traditionally, the prepositional object covers all such phrases headed by a preposition, other than the preposition used for the indirect object. Note, however, that direct objects that carry a preposition as a result of Differential Object Marking (DOM) (cf. \#\#Chapter II.2, Section 2.3) are not prepositional objects. Some examples:

(6) Fr. Je compte sur mes amis. 'I'm counting on my friends.'

(7) Sp. Ese trabajo carece de preparación. this work lacks of preparation

'This work lacks preparation.'

French $\grave{a}$, while being the preposition that heads indirect objects, is considered able to head also prepositional objects (Kotschi 1981). The feature distinguishing $\grave{a}$ as a head of an indirect object phrase from $\grave{a}$ as head of a prepositional object phrase is that for the prepositional object, the anaphor is the locative pronoun $y$ or $\grave{a}$ plus a stressed strong pronoun (à lui/elle) (8a), whereas for the indirect object, the anaphor is the personal pronoun luilelle $(8 \mathrm{~b})$ :

\begin{tabular}{|c|c|c|c|c|c|}
\hline a. Fr.Pierre & pense & $\begin{array}{ll}\grave{a} & s a \\
\end{array}$ & ville & natale ;- & il $y$ pense. \\
\hline Pierre & thinks & his & town & natal $\mathrm{h}$ & thinks \\
\hline 'Pierre & inks of & iis hometc & n. $\mathrm{He} \mathrm{t}$ & inks of it.' & \\
\hline b.Fr. Pierre & pense & $\begin{array}{l}\grave{a} \\
a\end{array}$ & mère, & lui & pense. \\
\hline Pierre & thinks & his & mothe & LUI & thinks \\
\hline
\end{tabular}

'Pierre thinks of his mother. He thinks of her.'

\subsubsection{Measure complements}

Measure complements are arguments that are not direct objects; i.e., they do not receive structural case merely by occupying a designated structural position (cf. \#\#Chapter II.2, Section 2). They share this characteristic with prepositional objects and indirect objects. However, unlike these, they are not PPs; rather, they are DPs or QPs. Unlike direct objects, they do not easily lend themselves to 
cliticization (9) - (10), although cliticization is not categorically impossible (11) (12) (data from Smith 1992):

(9) Sp. *Cien kilos, Juan los pesa. hundred kilos Juan them.ACC weighs. 'Juan weighs 100 kilos.'

(10) Fr.???Trois heures, ce concert les durera bien three hours this concert them.ACC last.FUT.3SG well 'This concert will well last three hours.'

(11) Fr. Trois aunes? Ce drap les a mesuré. three ells this cloth them.ACC has mesured 'Three ells? This cloth measured them.'

As Smith (1992) shows, measure complements also do not behave like objects where causativization, passivization, and agreement (12) are concerned. As a further distinction, Rizzi (1990) demonstrates that they cannot be extracted from $w h$-islands, again unlike direct objects:

(12) a. What did John wonder how to weigh? Apples.

b. What did John wonder how to weigh? *200 pounds.

Smith (1992) suggests that in French, and in Romance more generally, the same contrast obtains:

(13) a. Fr. Qu'est-cequ' il a décidé comment peser? Des what he has decided how weigh.INF ART.PL.INDF. pommes. apples

'What did he decide how to weigh? Apples.'

b. Fr. Qu'est-ce qu' il a décidé comment peser? *Cent what he has decided how weigh.INF hundred

kilos.

kilos

'What did he decide how to weigh? 100 kilos.'

\subsection{Distinguishing arguments from non-arguments}

As indicated in Section 1 above, early research into argument structure took lexical entries of verbs as starting point, and sought to characterize the semantic contribution associated with their grammatical relations. When adopting this semasiological perspective, a natural question arises: what are the grammatical relations that are actually required by a given verb at the level of its lexical entry? For example, in (14), it is quite straightforward to assume that the subject (je) is required by the lexical entry of remercier 'to thank'.

(14) Fr. Je vous remercie de tout mon cœur. I you.ACC.PL thank.1SG of all my heart 'I thank you from the bottom of my heart.'

However, can the same be said about the PP de tout mon cour, even when generalizing over verb meanings? Of course, similar questions can be asked for just about any verb. This was the starting point for a long and distinguished research programme into valency, to use Tesnière's (1959) term - how many, and of which type, grammatical relations come with a predicate? Historically, this 
research programme was pursued particularly vigorously in German Romance linguistics. In particular, it gave rise to valency dictionaries for a number of standard Romance languages: Busse/Dubost (1983) for French;

Blumenthal/Rovere (1988) for Italian; Busse et al. (1995) for Portuguese;

Engel/Savin (1983) for Romanian. These dictionaries aim at itemizing the valency of the language's verbal inventory items.

Despite this, though, it has never been possible to settle the underlying question in any given clause, is a given phrase lexically selected by the predicate or not? in a principled way. A number of criteria as a means to answering this question have been discussed.

The original valency criterion is obligatoriness, so that failure to verbalize a putative argument would result either in an ungrammatical utterance $(15 \mathrm{c} / \mathrm{d})$, or to a reading where the non-verbalized argument is understood as implied (cf. 16c/d). This contrasts with optionality of non-arguments $(15 \mathrm{a} / \mathrm{b}, 16 \mathrm{a} / \mathrm{b})$ :

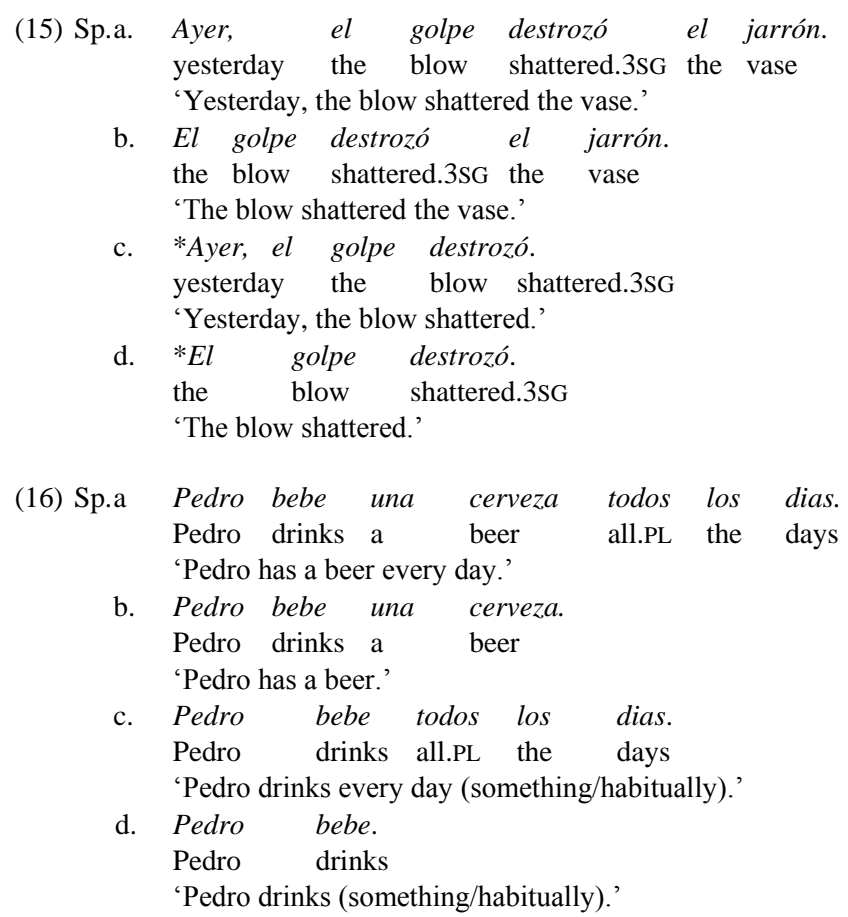

Thus, Spanish destrozar 'to destroy' and beber 'to drink' would be verbs with two arguments. The availability of a non-specific reading for a dropped complement as in (16d), though, makes obligatoriness a little less compelling criterion for argumenthood. After all, the non-specific reading implies that the argument is still there but not realized; this seems, at least in the first instance, to be conflicting with obligatoriness as essential to argumenthood.

In addition, clauses with a dropped argument that would be unacceptable when considered in isolation may be perfectly acceptable in context (Koch/Oesterreicher 1990, 77):

$\begin{array}{cccccll}\text { (17) Fr. Une fumée } & \text { pas } & \text { possible } & \text { CRAC } & \text { je } & \text { me } & \text { gare, } \\ \text { a } & \text { smoke } & \text { NEG } & \text { possible } & \text { I } & \text { myself } & \text { stop.1SG }\end{array}$


je soulève, ouh plus de moteur

I raise.1SG ouh no.more DET engine

'An incredible cloud of smoke, I stop, I open [the hood], oh no engine any more'

The verb soulever 'to raise' would normally require a direct object; nevertheless, in this context, where it is used without one, it is understood that the car's hood is the implied object, and the sentence is indeed acceptable. This makes obligatoriness a very unreliable criterion. Findings like this lead

Thompson/Hopper (2001) to question the very concept of argument structure. On the basis of frequency data, they argue that the co-occurrence of DPs and verbs in discourse is not so much guided by the selectional characteristics of lexical entries (as the notion of argument structure would suggest), but rather by speakers' stored knowledge of surface patterns of collocation.

The obligatoriness criterion construes argumenthood as very close in nature to complementhood. Complements are, in the broadest sense, what is required to make an expression complete, i.e., acceptable. For example, pasteur in French son père est pasteur 'his/her father is a minister' would be a complement. More narrowly and more commonly, complements are sister nodes of heads.

Another criterion for the distinction between arguments and non-arguments is syntactic mobility. Adjuncts are said to be more flexible in their syntactic position than arguments. Consider the event of thanking. It seems reasonable to assume that what somebody is thanked for is more specific to the event of thanking than the attitude of mind the thanking person has. This can correlate with a contrast in flexibility of position, cf. (18b) vs. (18d):

$\begin{aligned} & \text { (18) a. Fr. Je vous remercie de tout mon cour. } \\ & \text { I you.ACC.PL thank.1SG of whole my heart } \\ & \text { 'I thank you from the bottom of my heart.' } \\ & \text { b. Fr. De tout mon cour, je vous } \text { remercie. } \\ & \text { of whole my heart I you.ACC.PL thank.1SG } \\ & \text { 'I thank you from the bottom of my heart.' } \\ & \text { c. Fr. Je vous remercie d' être venu. } \\ & \text { I you.ACC.PL thank.1SG of be.INF come.PTCP } \\ & \text { 'I thank you for coming.' } \\ & \text { d. Fr. 'D' être venu, je vous } \\ & \text { of be.INF come.PTCP I you.ACC.PL thank.1SG } \\ & \text { 'I thank you for coming.' }\end{aligned}$

We would thus have established that what is being thanked for is an argument (d'être venu), whereas the attitude of mind adopted when thanking is an adjunct (de tout mon cour). However, the criterion of syntactic flexibility is not wholly reliable, either. Sometimes what would appear to be non-arguments cannot be preposed:

(19) a. Fr. Le poème se développe harmonieusement.
the poem itself develops harmoniously
'The poem unfolds harmoniously.'
b. Fr. 'Harmonieusement, le poème se développe.
harmoniously the poem itself develops
'The poem unfolds harmoniously.'

Conversely, sometimes phrases that arguably are arguments may be preposed: 
(20) a. Fr. J' ai offert ce livre à mon frère.

I have offered this book to my brother

'I offered this book to my brother.'

b. Fr. A mon frère, j' ai offert ce livre. to my brother I have offered this book 'I offered this book to my brother.'

More tests for argumenthood are reviewed in Jacobs (1994). The very fact that grammatical tests for argumenthood have been deemed unreliable affords one key insight: argumenthood is, ultimately, an intuitive notion that grammatical tests are merely trying to approximate; it reflects linguists' intuition about what they see as integral to an event-type. By the same token, the valency of any given verb cannot be determined with certainty. In fact, Jacobs (1994) argues in his critical discussion of valency theory, in particular of its long quest for a hard-and-fast test of the argument/adjunct distinction, that grammatical criteria like obligatoriness or syntactic flexibility cannot actually reveal argumenthood; rather, he suggests, they reflect an interpretation of what argumenthood means.

The difficulties in establishing criteria for argumenthood, and for valency of individual verbs, ultimately stem from the tension, referred to in Section 1, that arises from matching generalized and typified patterns of language structure to unique events. Thus, one might say that diverging tests for argumenthood reflect competition between theories of argument structure. Indeed, the reversal of perspective from a more semasiological (taking surface forms as starting point) to a more onomasiological perspective (taking events as starting points), alluded to in Section 1, has meant that current research is now much less occupied with establishing testable criteria for argumenthood.

\section{Argument structure of nouns and adjectives}

While verbs are specialized in the linguistic representation of events and are therefore the prototypical word class for argument structure, also other word classes may have an argument structure, in particular nouns and adjectives.

By morphological derivation, many verbs can be turned into nouns: French laver 'to wash' > lavage 'washing'; Italian elaborare 'to elaborate' > elaborazione 'elaboration'. Also, nouns can refer to the event described in a verb without being in a relation of morphological derivation with them in the contemporary grammar of the language: French chute 'fall' - tomber 'to fall'. These latter nouns are often called simple event nominals (Grimshaw 1990). With both nominalizations and simple event nominals, there can be a distinction between process and result readings. For example, Spanish aparcamiento can be both the 'action of parking a car' (22a) and the 'car park' (22b):

$\begin{array}{rllrl}\text { (21) a. Sp. Enrique } & \text { no obtuvo su permiso de conducir } \\ & \text { Enrique } & \text { NEG got.3SG his license of drive.INF } \\ & \text { porque } & \text { falló } & \text { en el aparcamiento. } \\ & \text { because } & \text { failed.3SG in the parking }\end{array}$

'Enrique did not get his driving license because he failed the parking test.' 
b. Sp. Esperaban en el aparcamiento.

waited.3PL.IPVF in the car.park

'They were waiting in the car park.'

Likewise, the French noun achat can refer to the purchase as a process (23a) and the item bought (23b):

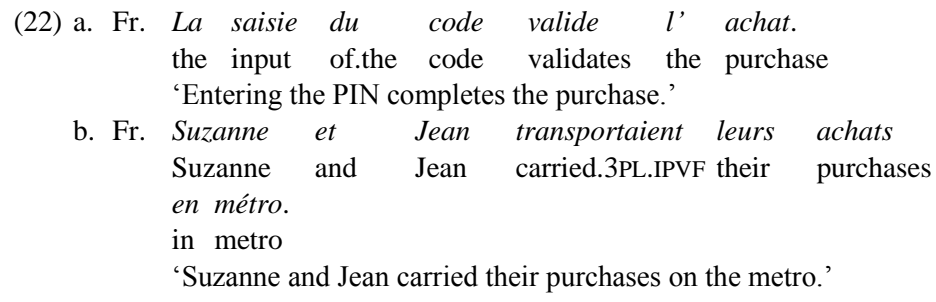

There is a link between the action of parking and the place where this action happened, and there is a link between the action of buying and the merchandise bought: they belong to the respectively same scenes or frames (cf. e.g., Detges 2004).

Nominalizations and event nominals can both have the same arguments as the verbs to which they are morphologically or conceptually related:
(23) a. Fr. Le téléphone était tombé sur le sol. The phone was fallen.M.SG on the floor 'The phone had fallen on the floor.'
b. Fr. La chute du telephonesur le sol the fall of.the phone on the floor 'The purchase of a car by P.'
(24) a. It. Abbiamo elaborato il programma dell' evento. have.3SG elaborated the programme of.the event 'We created the event's programme.'
b. It. la nostra elaborazione del programma dell' evento. the our.F elaboration of.the programme of.the event 'our creation of the event's programme'

What is the relationship between the argument structure of the verb and that of its corresponding event nominal or nominalization? According to the argument inheritance model (Grimshaw 1990; Olsen 1992; Harley 2009; among others), this relationship is a grammatical one, where morphological derivation involves, in some form, a transfer of the verb's argument structure to the derived noun. Lieber/Baayen $(1999,176)$ distinguish a "loose" version of argument inheritance from a "strict" one. In the "loose" version, nominalizing affixes perform operations on the underlying verb's argument structure, thus allowing for some variance between the underlying verb's and the resulting nominalization's argument structures. In the "strict" version, the underlying verb's argument structure is copied either faithfully to the nominalization's argument structure, or not at all.

Detges (2004) argues that the apparent similarity in participants observed in e.g. (23a) and (23b), and (24a) and (24b) respectively, is not the result of a transfer of argument structure by way of grammatical operation (argument inheritance), but a side-effect of something else, namely that morphologically related words, and in fact the various readings of polysemous lexical items, refer 
to aspects of meaning that are related by virtue of being about the same scene (cf. Detges 2004, 33). An argument for this hypothesis is that nouns that are neither morphologically nor semantically related to a base verb can apparently take arguments in a similar way to those that are (cf. Detges 2004, 30-31 for this point):

$\begin{array}{rlll}\text { (25) a. Pt. } & \text { o planeador desta casa } \\ \text { the planner of.this } & \text { house } \\ \text { 'the planner of this house' } & \\ \text { b. Pt. } & \begin{array}{l}\text { arquitecto desta } \\ \text { the architect of.this }\end{array} & \text { house } \\ & \text { 'the architect of this house' }\end{array}$

The verb planear 'to plan' denotes an event; the noun planeador is morphologically derived from it, and it can take an argument that is very similar to one the verb planear would take as in, say, planear uma casa 'to plan a house'. Now, the morphologically simple noun arquitecto, similar in meaning to the noun planeador, can take what appears to be the same argument, even though it cannot conceivably have inherited this argument in a morphology-based grammatical process. In fact, it is common for nouns to take arguments of their own, in particular relational nouns (mother, colleague, etc.). Thus, the argument Detges is making is that the capacity of nouns to head dependent phrases is based on the conceptual scene they are profiled against, just as in fact with verbs, rather than being the result of a designated grammatical process of argument inheritance.

A similar argument can be made about adjectives. Adjectives modify nouns and verbs (cf. \#\#Chapter IV.21). In turn, they can be the head of PPs and complement clauses (Noailly 1999):

(26) a. Fr. une maison identique à une autre a house identical to a other 'a house identical to another one'

b. Fr. désireux que tout se passe bien eager that everything itself goes well 'wishing that everything goes well'

As Noailly $(1999,70)$ points out, complement clauses governed by French adjectives, even if not headed by a preposition, behave syntactically not like direct objects, since their anaphor is the adjunct pronoun en, rather than the direct object pronoun le. Compare (27a) and (27b):

(27) Fr.a. Blaise est désireux que tout se passe bien. Blaise is eager that everything itself goes well Il $\left(e n / *^{\prime}\right)$ est désireux.

he $(\mathrm{EN} / *$ it.ACC $)$ is eager

'Blaise is wishful for everything to go well. He is wishful of this.'

b. Blaise desire que tout se passe bien.

Blais wishes that everything itself goes well

Il $(l e / * e n)$ desire.

$\mathrm{He}$ (it.ACC/EN) wishes.

'Blaise wishes that everything goes well. He wishes it.'

However, Noailly $(1999,73)$ also points out that the pronouns en and $y$ can be anaphors of adjectival complements only if these adjectives are used in combination with copular verbs, as indeed in (27a). 


\section{Linking in Romance Languages}

We saw in Section 1 that the linguistic representation of events relies on generalized patterns of splitting events into predicates and arguments, where the surface expression of arguments (grammatical relations) and their function (semantic role) are paired. The pairing patterns are called the linking process. We will now look at some of the main issues of linking found in Romance languages.

\subsection{The accusative linking type}

Typologically speaking, Romance languages belong, at the highest level of generalization, to the "accusative" linking-type. In this linking-type, verbs have thus obligatory subject arguments, which can host a large variety of semantic roles (cf. \#\#Chapter II.1). In particular, predicates with (28a) or without (28b) an AGENT role have a grammatical subject:
(28) a. Sp. Carlos trabajaba todos los dias.
Carlos worked.3SG.IPFV all.PL the days
'Carlos was working every day.'

b. Sp. Ana estaba en su piso.

Ana was.IPFV in her flat

'Ana was in her flat.'

This is in contrast to another major high-level linking pattern found across languages, the "ergative" type. In this linking-type, most generally speaking, the "subject of an intransitive clause is treated in the same way as the object of a transitive clause, and different from transitive subject" (Dixon 1994, 1). One example for this is Basque:

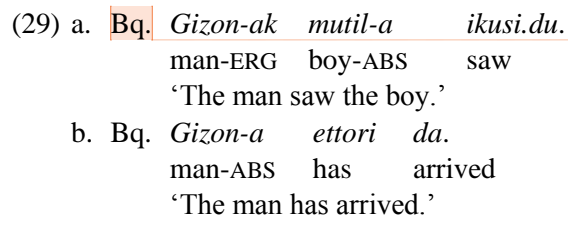

The default argument form-type is the absolutive case (mutila in (29a), gizona in (29b)). If the predicate has an agent, as in (29b), then this AGENT is encoded in the ergative form-type, while the other role is still encoded in the default 'absolutive' argument type.

Having said this, there is one distinctive feature that figures prominently in discussions about the top-level linking type Romance languages belong to: past participle agreement. Past participle agreement can be seen as a form of object agreement:

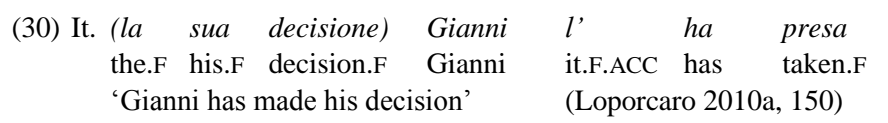

In modern Romance standard languages, past participle agreement with the direct object obtains only in a subset of syntactically defined contexts (cf. Loporcaro 2010b for a detailed breakdown, including a pattern of implicational relations between these contexts). However, in some varieties, it obtains across 
the board, including with lexical direct objects in canonical post-verbal position, as in the following example from Neapolitan, from Loporcaro (2010a, 226):

$\begin{array}{lllll}\text { (31) Np. } & \text { ałд } \quad \text { køttə/ } & * k w e t t \partial & \text { la } & \text { past } \\ \begin{array}{l}\text { have.1SG cooked.F } \\ \text { 'I cooked the pasta.' }\end{array} & \text { cooked.M } & \text { the.F } & \text { pasta.F } \\ & & \end{array}$

In other varieties, it is optional in that context, such as in Périgord Occitan (cf. Miremont 1976, 53, apud Loporcaro 2010b, 233):

$\begin{array}{lllll}\text { (32) POcc. } & \text { Avem } \quad \text { fach/ } & \text { facha } & \text { la } & \text { paz. } \\ \text { have.1PL made.M } & \text { made.F. } & \text { the.F } & \text { peace.F } \\ \text { 'We made peace.' } & & & \end{array}$

Commented [A9]: abbreviation?

Also, La Fauci (1994) and Loporcaro (e.g. 2010a, 2010b) assume that in Proto-Romance, past participle agreement of lexical direct object with transitive verbs was obligatory. This assumption crucially hinges on another assumption, though, namely that in Proto-Romance, the past participle in combination with transitive verbs had already been reanalysed from a resultative construction to a perfective tense (cf. \#\#\#Chapter ??). Otherwise the past participle agreement would not reflect agreement with the verb (i.e., indicating object agreement), but merely agreement within the DP. See the following example from the Novellino (late 13th century), from Loporcaro (2010b, 232):

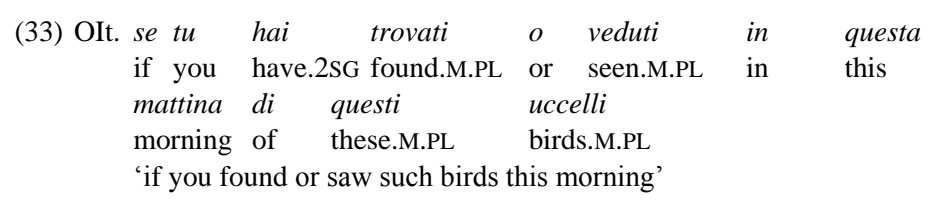

In other words, Neapolitan, as in (31), would simply be a particularly conservative Romance variety, and Périgord Occitan (32) would have moved a little closer towards the present standard Romance pattern.

La Fauci (1994) and Bentley (2006) see the object agreement inherent in past participle agreement as indicative of a partial departure from the accusative coding pattern during the transition from Latin to Romance. They cast their analyses in Relational Grammar terms. The 'pure' accusative type does not grammatically reflect the semantic relatedness of direct objects of transitive verbs on the one hand, and subjects that are 'middle' on the other hand. This was arguably the situation in Latin. In Relational Grammar, a 'middle' construction has a surface subject that is also a direct object at some earlier stage in the structural derivation (La Fauci 1994, 41). Examples for 'middle' constructions are passives and reflexive clauses. Past participle agreement, now, is shared by direct objects of transitive verbs and subjects of middle constructions, namely when the latter have a perfect auxiliary whose linguistic ancestor is Latin ESSE (La Fauci 1994, 50). Past participle agreement (whether with the auxiliary HABERE or with the auxiliary ESSE) creates thus a link between transitive direct objects and middle subjects, and its assumed obligatoriness in Proto-Romance would indicate a partial shift from the accusative type towards the ergative type. The later retreat of direct object part participle agreement in most, though not all, Romance varieties is indicative of a reversal (albeit incomplete) of this shift, moving back towards the accusative type (La Fauci 1994).

More broadly, Loporcaro (2011) argues that object agreement is only one example of active alignment in Romance, i.e., a grammatically encoded 
prominence of the AGENT (as opposed to not overtly distinguishing between unergative and unaccusative subjects, as is characteristic of accusative languages). As a further example, he cites perfect auxiliary choice. With pure accusative alignment, there would be only one perfect auxiliary. The choice between ESSE and HABERE auxiliaries in Romance languages, however, reflects a fine gradation between the unaccuative and the unergative type. In other words, active alignment is not as uncommon in Romance as the accusative linking-type would imply.

\subsection{Impersonal verbs}

One exception to the obligatoriness of the subject as implied by the accusative linking-type are impersonal verbs (cf. also \#\#Chapter II.1).

Impersonal verbs can come with (34a) or without (34b) an expletive subject.

$$
\begin{aligned}
\text { (34) a. Fr. } & \text { Il pleut. } \\
& \text { it.EXPL rains } \\
& \text { 'It rains.' }
\end{aligned}
$$

b. Sp. Nevica

snows

'It snows.'

In some varieties, there are strong pronouns that can be used as expletive subjects, including in the null-subject languages. (35a) is from Dominican Spanish (Henríquez Ureña 1940, 226-228, cited in Hinzelin/Kaiser 2006); whereas (35b) is from Colloquial French:

$$
\begin{array}{lll}
\text { (35) a. DomSp. } & \begin{array}{l}
\text { Ello hay } \\
\text { it }
\end{array} \\
& \text { 'There is maize.' } & \text { maíz. } \\
\text { b. Fr. } & \text { Ça flotte. } \\
& \text { it floats } \\
& \text { 'It rains cats and dogs.' }
\end{array}
$$

Chomsky (1981) proposed that there are two types of impersonal pronouns (whether surfacing as an expletive subject or not): those that are neither referential nor occupying an argument position, and those that are not referential but occupy an argument position. The latter are also called quasi-arguments.

Kaiser/Oliviéri/Pelasis (2013) argue that this distinction is morphologically reflected in the Corrèze variety of Northern Occitan: whereas the expletive pronoun $k o$ is used with quasi-arguments (36a), there is no pronoun at all with entirely impersonal verbs (36b) (data from Kaiser/Oliviéri/Pelasis 2013):

$$
\begin{gathered}
\text { (36) a. Occ. } k s \quad p l^{\prime} \phi j \\
\text { it.EXPL rains } \\
\text { 'it is raining' } \\
\text { b. Occ. } s^{\prime} \varepsilon b l \\
\text { seems } \\
\text { 'it seems' }
\end{gathered}
$$

Kaiser/Oliviéri/Pelasis (2013) also suggest that this morphological split between quasi-arguments and entirely impersonal verbs is, diachronically speaking, an intermediate stage, since in the neighbouring variety of Creuze Occitan, the pronoun $k o$ has spread to a large number of those contexts that have no pronoun at all in Corrèze Occitan. 


\subsection{Transitivity}

As a generalization over linking in accusative languages, whenever a predicate has an overtly expressed AGENT, the agent will be the subject of the active clause. As suggested in Section 1, the subject is semantically the most flexible type of grammatical relation, followed by the direct object . The indirect object, most commonly, represents a BENEFICIARY role. Prepositional objects are often very transparent in their role-semantic meaning; more specifically, when this meaning reflects the lexical meaning of the preposition that heads the prepositional phrase.

Not only are Romance languages accusative languages and have thus obligatory subjects (whether overtly expressed or pro), they also widely use the direct object in active transitive sentences irrespective of the latter's semantic role, thus generalizing the subject-direct object pattern (syntactic transitivity). Geisler $(1988,27)$ points out that a number of Modern French verbs with a subject-direct object pattern had different form-types in previous stages of the language:

\begin{tabular}{|l|l|l|}
\hline Old French & Modern French & Gloss \\
\hline$X$ me poise & je regrette $X$ & 'I regret X' \\
\hline$X$ me loist & je peux faire $X$ & 'I am at liberty to do X' \\
\hline m'estuet faire $X$ & je dois faire $X$ & 'I need to do X' \\
\hline
\end{tabular}

Table 2: Changes in transitivity in French (Geisler 1988)

Table 2 shows that in Old French, the EXPERIENCER role was encoded as indirect object ( $m e$ 'to me'); in Modern French, it is a subject (je ' $\mathrm{I}$ '). Taken together, Modern French has a split linking pattern where the subject and direct object function are relatively unmotivated (i.e., they are compatible with a wide range of semantic roles), whereas indirect and prepositional objects are more transparent (i.e., they are compatible only with a small range of semantic roles).

Where Spanish is concerned, Vázquez Rozas (2006) argues that that language continues to have a more motivated linking pattern, with a more systematic mapping of EXPERIENCER roles to indirect objects, thus eschewing the relative uniformity of the French-type subject-object structure. Some examples for this pattern (from Vázquez Rozas 2006, 80):

(37) Sp. Me gustó el libro.

me.DAT enjoyed.3SG the book

'I liked the book.'

(38) Sp. A Miguel ya no le apetecía jugar

to Miguel already NEG him.DAT temtped.3SG.IPFV play.INF

al parchís.

at.the Parcheesi

'Miguel did not feel like playing Parcheesi anymore.'

However, when the experiencer participant has greater agency and the event is dynamic and telic, the subject-object coding pattern is preferred (examples from Vázquez Rozas 2006, 99):
(39) a. Sp. Intentó olvidar a María.
tried.3SG forget.inf A María
'S/he tried to forget María.'
b. Sp. *Intentó que se le olvidara María. tried.3SG that REFL.3 him.DAT forget.PST.SBJV.3SG María 'S/he tried to forget María.'


More broadly, with the argument structure of "psych"-verbs like Spanish gustar 'to enjoy', there is a linking conflict that can be expressed in terms of Dowty's (1991) proto-role entailments. Both the experiencer participant and the phenomenon participant have AGENT proto-role as well as PATIENT proto-role characteristics. The experiencer participant may have the AGENT proto-role properties of volitional involvement, sentience, and existence independent of the event. However, it also may have the PATIENT proto-role characteristics of being causally affected by another participant, undergoing a change of state, and being stationary relative to another participant. Conversely, the phenomenon participant may have the AGENT characteristics of causing an event and existence

independent of the event; and it may have the PATIENT characteristics of not existing independently of the event, and undergoing a change of state. This conflict leads to a good deal of inter-linguistic variability in the matching of EXPERIENCER and PHENOMENON with the subject grammatical relation, even among closely related Romance languages (examples from a comparison of translations, Koch 2001):

(40) Pt. Mas gostava mais dela com os cabelos soltos. but enjoyed.3SG more of.her.DAT with thehair.PL loose.PL

(41) It. Ma a me piaceva di più con $i$ capelli liberi. but to me.DAT pleased.3SG.IPFV of more with the hair.PL free.PL 'But I liked her better with her hair loose.'

(42) Fr. J' aime la fraîcheur des bois et la tranquillité I like the coolness of.the woods and the tranquillity champêtre $[\ldots]$ rustic

(43) Cat. $M^{\prime} \quad$ agrada la frescor dels boscos $i$ la me.DAT pleases the coolness of.the woods and the tranquil.litat campestre $[\ldots]$ tranquillity rustic

'I love cool forests and rustic tranquillity.'

The coding conflict also can be held responsible for diachronic change within languages. Latin inodiare 'to hate', with an EXPERIENCER subject, is the etymon of French ennuyer, Spanish enojar, and Italian annoiare 'to be bored', all of which have a PHENOMENON subject (Koch 2001, 74):

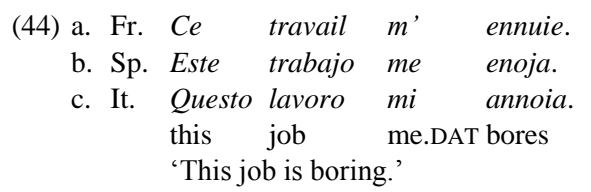

Romanian a plăcea 'to please' has a long-standing linking pattern with a PHENOMENON subject (cf. Koch 2001, 75):
(45) Rom. Ĭmi place muzica simfonică. me.DAT pleases music.the symphonic 'I like symphonic music'.

However, this verb also has a more recent use with an EXPERIENCER subject (cf. Koch 2001, 75): 
(46) Rom. Eu nu te plac.

I NEG you.ACC please.1SG

'I don't like you.'

Similarly, but proceeding in the opposite direction, Spanish gustar had a transitive linking pattern with an experiencer subject (examples from Vázquez Rozas 2006, 110):

(47) Sp. [..] si ya no gustas que la discreción y

if already NEG please.2SG that the discretion and

sciencia de Tirsi y de Demón te alumbren

science of Tirsi and of Damon you.ACC enlight.3PL

de la ceguedad en que estás [...]

of the blindness in that stay.2SG

'if you don't like that the discretion and science of Tirsi and Damon enlight your blindness'

Only since the eighteenth century does Spanish have the current pattern with the PHENOMENON subject (Vázquez Rozas 2006, 96).

\section{Argument alternations}

Very often, verbs do not have just a single arrangement of arguments. Some of this is idiosyncratic polysemy or homonymy. For example, the French verb tirer 'to pull, to draw' allows the following constructions:

(48) a. Fr. Luc tire la sonnette $d$ ' alarme.

Luc pulls the bell of alarm

Luc sounds the alarm bell.'

b. Fr.Marie tire sur la cible.

Marie shoots on the target

'Marie shoots the target.'

(48a) has a direct object, (48b) a prepositional object, and both verbs have very different meaning. This kind of alternation is not repeated across French verbs, and it appears to be relatively idiosyncratic.

Some alternations are not repeated across verbs of the same language, but the same or a similar type of alternation may recur in other languages. For example, across Romance languages, the verbs for 'to rent' and 'to rent out' allow, up to a point, a shuffling of the 'tenant' and 'landlord' roles (cf. Koch 1991):

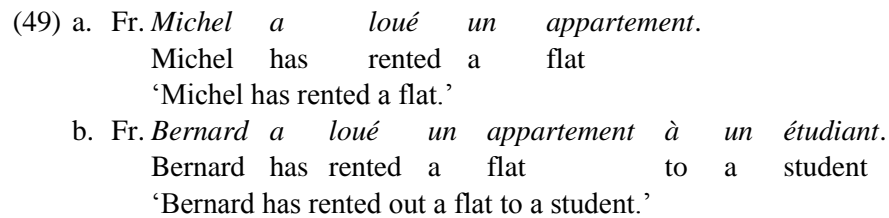

b. Fr. Bernard a loué un appartement à un étudiant. Bernard has rented a flat to a student

'Bernard has rented out a flat to a student.'

(50) a. It. Gianni ha affittato una casa in via Garibaldi. Gianni has rented a house in via Garibaldi 'Gianni has rented a place in via Garibaldi.'

b. It. Affittavano la loro casa mentre stavano in rented.3PL.IPFV the their house while stayed.3PL.IPFV in 


\section{Inghilterra.}

England

'They rented out their flat while they stayed in England.'

More importantly though, there are relatively "generalized" patterns of variation recurring across many verbs in the language, where the difference in perspective on the same event described in Section 1, reflected in the choice of different verbs referring to the same scene, is replicated at a lower level by different argument patterns of the same verb. In other words, generalized alternation is rooted in the selectivity and perspective inherent in the verbalization of events. Generalized alternation, where it is available, reflects the frequency that the distinctions it implies have in conversation. For example, many French verbs allow variation along the following lines:

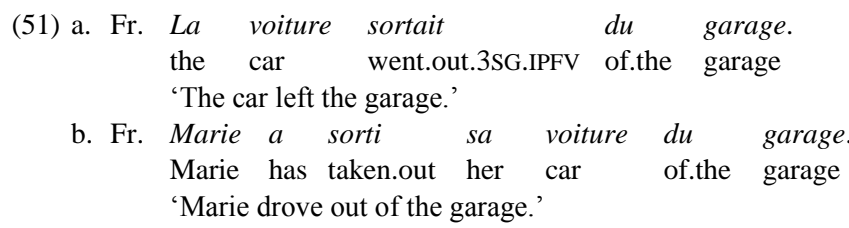

(51a) and (51b) can represent the same event; whereas (51a) only implies an agent, though, that agent is made explicit in (51b). (51a) is the anticausative variant of (51b). An explanation for the fact that the anticausative alternation is so wide-spread can be sought in the communicative importance of distinguishing between events with an identified agent and those without one.

In the following, some of the most well-known types of generalized alternation will be discussed.

\subsection{Anticausatives}

Anticausatives are argument structure alternations where the same verb has a transitive variant with an agent and a (transitive or intransitive) variant without an agent. The object of the transitive variant has the same semantic role as the subject of the anticausative variant. In Romance languages, anticausatives are of two main types: an intransitive unmarked (i.e., anticausativity is not signalled by a special morpheme) and a transitive reflexive one (cf. Oesterreicher 1992, Heidinger 2010). The unmarked anticausative is also an unaccusative verb, i.e., an intransitive verb whose single argument is not an agent (cf. \#\#Chapter II.1).

The following pairs or triplets of examples show the transitive variant with the unmarked intransitive anticausative (52), the reflexive anticausative (53), or both (54).

\footnotetext{
(52) a. It. Luigi ha uscito la Maserati dal parcheggio Luigi has taken.out the Maserati of.the car.park 'Luigi drove the Maserati out of the car park.'

b. It. $\mathrm{La}$ Maserati $\grave{e}$ uscita dal parcheggio. the Maserati is left of.the car.park

'The Maserati left the car park.'
}

Commented [ES13]: Editors: check whether this notion is defined in the voice chapter and cross-reference 


(53) a. Sp.La piedra rompió la ventana.
the stone broke.3SG the window
'The stone broke the window.'
b. Sp.La ventana se rempió.
the window REFL 3 broke.3SG
'The window broke.'
(54) a. Fr. Gérard a cassé la branche.
Gerard has broken the branch
'Gérard broke the branch.'
b. Fr. La branche a
the branch has
'The branch broke.'
c. Fr. La baken branche $s$, est cassée.
the branch.F REFL.3 is broken.F
'The branch broke.'

All Romance languages have the reflexive anticausative alternation. The unmarked anticausative alternation is quite common in French (54b), where the verbs allowing it are also known under the name of "symmetrical verbs" (Rothemberg 1974). Another name for verbs affected by this alternation are "ergative verbs", inspired by the name for the ergative coding pattern as used in linguistic typology (cf. Comrie 1978; Plank 1979; Dixon 1994). Rothemberg (1974) lists more than 300 French verbs of this type. The alternation is not available across the board, though:

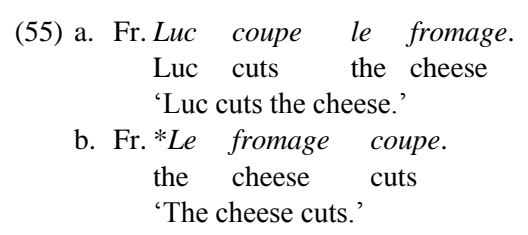

The unmarked anticausative is more restricted in the other Romance languages - there are only about 30 such verbs in Spanish (Kailuweit 2012). Heidinger (2010) has found that in French, the reflexive anticausative began to compete with the unmarked one from the twelfth century as a synonymous alternative. Over the history of French, the relative frequency of the reflexive anticausative, as opposed to the unmarked anticausative, has greatly increased. While Heidinger has found no hard-and-fast rule governing the choice between unmarked causative and reflexive anticausative (both are available, in principle, in all the semantic verb classes he distinguishes), he notes that reflexive

anticausatives are increasingly dominating in change-of-state verbs (e.g. durcir 'to harden', renouveler 'to renew', gonfler 'to swell') and with inanimate subjects. Geisler (1988, 31-32) sees the apparently increasing reliance on reflexive anticausatives (as opposed to unmarked, intransitive anticausatives) as part of the broad diachronic trend towards the generalization of the transitive subject-object coding pattern. The idea here is that, as subjects in Modern French transitive clauses do not need to be as high in agency as in Old French, let alone Latin, they become available for the representation of less semantically transitive (Hopper/Thompson 1980) events. As a result, the subject-object coding pattern can accommodate events with just one participant, as anticausatives indeed are. 


\subsection{Locative alternations}

A number of French verbs allow alternations in the expression of the relation between 'containers' and 'contents':

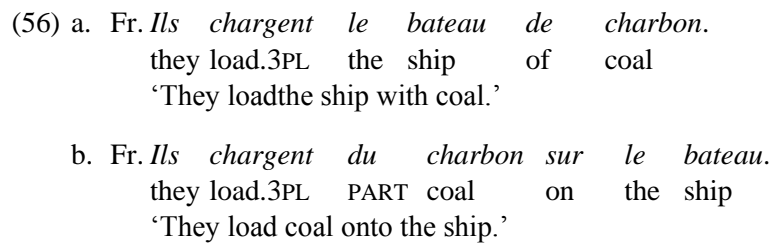

In (56a), the direct object represents the 'container'; in (56b), it represents the 'content'. Other examples for this alternation are:

(57) a. Fr. Max perce le mur de trous.
Max drills the wall of holes
'Max drills holes into the wall.'
b. Fr. Max perce des trous dans le
Max drills some holes in the ticket
'Max drills holes into the wall.'
(58) a. Fr. Léa incruste le metal d' émail.
Léa encrusts the metal of enamel
'Léa encrusts the metal with enamel.'
b. Fr. Léa incruste de l' émail dans le metal.
Léa encrusts of the enamel in the metal
'Léa encrusts enamel on the metal.'

There is a holistic effect with the 'container' direct object (the ' $b$ ' variant in (56-58)): the 'container' (the ship, the wall, the piece of metal) is wholly affected. That is, the ship is fully loaded, the wall has been penetrated, the piece of metal is fully encrusted. Note, however, that there is some leeway for variation left. In other words, the ship need not be loaded to maximum capacity; it is sufficient that it carries what can pragmatically be accepted as a "full load".

The verbs relevant to this alternation have an incremental theme (Dowty 1991), i.e., the degree of completion of the event is reflected in the extent to which the THEME object is affected. The loading process is half complete when half of the ship's loading compartment is filled, and it is complete when the loading compartment is filled.

The alternation ultimately reflects the close semantic relationship that exists between containers and their contents. This motivates a change in perspective for the otherwise same kind of event.

\subsection{The "swarm"-alternation}

Another generalized alternation relying on the container-content relationship is the "swarm"-alternation, where arguments can switch between subject and a prepositional object:

(59) a. Fr. Le ciel brille d' étoiles. the sky shines of stars 'The sky is glistening with stars.' 
b. Fr.Les étoiles brillent au ciel.

the stars shine.3PL at.the sky

'Stars are glistening in the sky.'

(60) a. Fr. La baignoire déborde d' eau. the bathtub overflows of water

'The bathtub is overflowing with water.'

b. Fr. $L$ ' eau déborde de la baignoire. the water overflows of the bathtub

'Water is overflowing from the bathtub.'

(61) a. It. La casa risuona di voci allegre.

the house resounds of voices happy.PL

'The house is resounding with happy voices.'

b. It. I canti risuonano nella casa.

the songs resound.3PL in.the house

'The singing is resounding in the house.'

There is much debate about the precise semantic requirements for a verb to be capable of this alternation (e.g., Levin/Rappaport Hovav 1995; Hoeksema 2008; Mayoral Hernández 2007). In particular, the relationship of this alternation to the locative alternation is not fully understood. Clearly it is not every

container/content relationship that can enter it; there are additional requirements that seem to make verbs of sound and light emission (e.g. resounding, glistening) particularly suitable. As with the locative alternation, there is a holistic effect in the "swarm"-alternation, which is strongest when the 'container' is in the subject position. Unlike locative alternations, though, there is no incremental theme here.

\section{Conclusion}

Argument structure is a focal point for the understanding of grammatical structure. Whereas it was mostly regarded as an interface between syntax and lexicon in the 1970s and 1980s, linguists now appreciate the richness of argument structure and the diversity of its ramifications that resists any easy categorization. In particular, what perhaps sets argument structure apart from other domains of grammatical description are the vast differences in granularity at which it operates - from high-level generalizations, that amount to typological differences between sets of languages, to very low-level ones that may apply to just one verb. Perhaps argument structure is the domain of grammar that most directly reflects extralinguistic experience and information.

\section{References}

Bentley, Delia (2006), Split intransitivity in Italian, Berlin, Mouton de Gruyter. Blumenthal, Peter/Giovanni Rovere (1988), Wörterbuch der italienischen Verben. Konstruktionen, Bedeutungen, Übersetzungen, Stuttgart, Klett.

Busse, Winfried/Dubost, Jean-Pierre (1983), Französisches Verblexikon. Die Konstruktion der Verben im Französischen, Stuttgart, Klett.

Busse, Winfried et al. (1995), Dicionário sintáctico de verbos portugueses, Coimbra, Almedina.

Chomsky, Noam (1981), Lectures on government and binding, Dordrecht, Foris. 
Comrie, Bernard (1978), Ergativity, in: Winfred P. Lehmann (ed.), Syntactic typology: Studies in the phenomenology of language, Austin, University of Texas Press, 329-394.

Comrie, Bernard/Smith, Norval (1977): Lingua descriptive studies: questionnaire, Lingua 42, 1-72.

Croft, William (2012), Verbs. Aspect and causal structure, Oxford, Oxford University Press.

Detges, Ulrich (2004), Argument inheritance as a metonymic effect. Metaphorik.de 6, http://www.metaphorik.de/sites/www.metaphorik.de/files/journalpdf/06_2004_detges.pdf (last access: 28/04/2016)

Dixon, Robert M. W. (1994), Ergativity, Cambridge, Cambridge University Press.

Dowty, David (1991), Thematic proto-roles and argument selection, Language 67, 547-619.

Du Bois, John W. (2003), Argument structure. Grammar in use, in: John W. Du Bois/Lorraine E. Kumpf/William J. Ashby (eds.), Preferred Argument Structure. Grammar as architecture for function, Amsterdam/Philadelphia, John Benjamins, 13-59.

Engel, Ulrich/Emilia Savin et al. (1983), Valenzlexikon Deutsch-Rumänisch. Dicţionar de valenţă german-român, Heidelberg, Julius Groos.

Fillmore, Charles J. (1968), The case for case, in: Emmon Bach/Robert T. Harms (eds.), Universals in Linguistic Theory, New York, Holt, Rinehart and Winston, $1-88$.

Fillmore, Charles J. (1971), Types of lexical information, in: Danny D. Steinberg/Leon A. Jakobovits (eds.), Semantics, Cambridge, CUP, 370-92.

Fillmore, Charles J. (1977), Scenes-and-frames semantics, in: Antonio Zampolli (ed.), Linguistic Structures Processing, Amsterdam, North-Holland, 55-81.

Geisler, Hans (1988), Das Verhältnis von semantischer und syntaktischer Transitivität im Französischen, Romanistisches Jahrbuch 39, 22-35.

Grimshaw, Jane (1990), Argument Structure, Cambridge/MA, The MIT Press.

Harley, Heidi (2009), The morphology of nominalizations and the syntax of $v P$, in: Monika Rathert/Anastasia Giannadikou (eds.), Quantification, Definiteness and Nominalization, Oxford, OUP, 320-342.

Heidinger, Steffen (2010), French anticausatives. A diachronic perspective, Berlin, de Gruyter.

Henríquez Ureña, Pedro (1940), El español en Santo Domingo, Santo Domingo, Editora Taller.

Hinzelin, Marc-Olivier/Kaiser, Georg (2006), Das neutrale Pronomen ello im dominikanischen Spanisch und die Nullsubjekteigenschaft, Konstanz, FB Sprachwissenschaft (Arbeitspapier 116).

Hoeksema, Jack (2008), The swarm-alternation revisited, in: Erhard Hinrichs/John Nerbonne (eds.), Theory and Evidence in Semantics, Stanford, 53-80.

Hopper, Paul J./Thompson, Sandra A. (1980), Transitivity in grammar and discourse, Language 56, 251-299.

Jackendoff, Ray S.per (1990), Semantic structures, Cambridge/MA, The MIT Press.

Jacobs, Joachim (1994), Kontra Valenz, Trier, Wissenschaftlicher Verlag.

Kailuweit, Rolf (2012), Construcciones anticausativas: el español comparado con el francés, in: Valeriano Bellosta von Colbe/Marco García García (eds.), Aspectualidad - transitividad - referencialidad. Las lenguas románicas en contraste, Frankfurt, Lang, 133-158.

Kaiser, Georg/Oliviéri, Michèle/Pelasis, Katerina (2013), Impersonal constructions in Northern Occitan, in: Ernestina Carrilho et al. (eds.), Current Approaches to Limits and Areas in Dialectology, Newcastle, Cambridge Scholars Publishing, 345-367. 
Koch, Peter (1981), Verb - Valenz - Verfügung. Zur Satzsemantik und Valenz französischer Verben am Beispiel der Verfügungs-Verben, Heidelberg, Winter

Koch, Peter (1991), Semantische Valenz, Polysemie und Bedeutungswandel bei romanischen Verben, in: Peter Koch/Thomas Krefeld (eds.), Connexiones Romanicae. Dependenz und Valenz in romanischen Sprachen, Tübingen, Niemeyer, 297-306.

Koch, Peter (2001), As you like it. Les métataxes actancielles entre expérient et phénomène, in: Lene Schøsler (ed.), La valence, perspectives romanes et diachroniques, Stuttgart, Franz Steiner, 59-81.

Koch, Peter/Oesterreicher, Wulf (1990), Gesprochene Sprache in der Romania: Französisch, Italienisch, Spanisch, Tübingen, Niemeyer.

Kotschi, Thomas (1981), Verbvalenz im Französischen, in: Thomas Kotschi (ed.), Beiträge zur Linguistik des Französischen, Tübingen, Narr, 80-122.

La Fauci, Nunzio (1994), Objects and subjects in the formation of Romance morphosyntax, Bloomington, Indiana University Linguistics Club.

Levin, Beth/Malka Rappaport Hovav (1995), Unaccusativity: At the syntax-semantics interface. Cambridge, MA, The MIT Press.

Levin, Beth/Malka Rappaport Hovav (2005), Argument realization. Cambridge, CUP.

Lieber, Rochelle/Harald Baayen (1999), Nominalizations in a calculus of lexical semantic representations, in: Geert Booij/Jaap van Maarle (eds.), Handbook of morphology, Dordrecht, Kluwer, 175-198.

Loporcaro, Michele (2010a), Variation and change in morphology and syntax. Romance object agreement, in: Franz Rainer et al. (eds.), Variation and Change in Morphology. Selected papers from the 13th International Morphology Meeting, Vienna, February 2008, Amsterdam/Philadelphia, Benjamins, 149-175.

Loporcaro, Michele (2010b), The logic of past participle agreement, in: Roberta D'Alessandro/Adam Ledgeway/ Ian Roberts (eds.), Syntactic Variation. The Dialects of Italy, Cambridge, Cambridge University Press, 225-243.

Loporcaro, Michele (2011): Two euroversals in a global perspective: auxiliation and alignment, in: Peter Siemund (ed.), Linguistic universals and language variation, Berlin, de Gruyter Mouton, 55-91.

Mateu, Jaume (2012), Structure of the verb phrase, in: Jose Ignacio Hualde/Antxon Olarrea/Erin O'Rourke (eds.), The handbook of Hispanic linguistics, Oxford, Blackwell, 333-353.

Mayoral Hernández, Roberto (2007), A variation study of verb types and subject position: Verbs of light and sound emission, in: José Camacho et al. (eds.), Romance Linguistics 2006. Selected papers from the 36th Linguistic Symposium on Romance Languages (LSRL), New Brunswick, March-April 2006, Amsterdam/Philadelphia, John Benjamins.

Miremont, Pierre (1976), La syntaxe occitane du Périgord, Toulouse.

Noailly, Michèle (1999), L'adjectif en français, Paris, Ophrys.

Oesterreicher, Wulf (1992). SE im Spanischen. Pseudoreflexivität, Diathese und Prototypikalität von semantischen Rollen, Romanistisches Jahrbuch 43, 237-260.

Olsen, Susan (1992), Zur Grammatik des Wortes. Argumente zur Argumentvererbung, Linguistische Berichte 137, 3-32.

Plank, Frans (ed.) (1979), Ergativity: Towards a theory of grammatical relations, London, Academic Press.

Rappaport Hovav, M./Beth Levin (1998), Building Verb Meanings, in: Miriam Butt/Wilhelm Geuder (eds.), The Projection of Arguments: Lexical and Compositional Factors, Stanford, CA, CSLI, 97-134.

Rizzi, Luigi (1990), Relativized minimality, Cambridge, MA, The MIT Press.

Rothemberg, Mira (1974), Les verbes à la fois transitifs et intransitifs en français contemporain, The Hague, Mouton. 
Salvi, Giampaolo (2001), La frase semplice, in: Lorenzo Renzi/Giampaolo Salvi/Anna Cardinaletti (eds.), Grande grammatica italiana di consultazione, Bologna, Il Mulino, vol. I, 37-127.

Smith, John Charles (1992). Circumstantial complements and direct objects in the Romance languages: configuration, case, and thematic structure, in: Iggy Roca (ed.), Thematic structure. Its role in grammar, Berlin/New York, Foris, 293-316.

Tesnière, Lucien (1959), Eléments de syntaxe structural, Paris: Klincksieck.

Thompson, Sandra A/ Hopper, Paul J. (2001), Transitivity, clause structure, and argument structure: Evidence from conversation, in: Joan L. Bybee/Paul Hopper (eds.), Frequency and the Emergence of Linguistic Structure,

Amsterdam/Philadelphia, John Benjamins, 27-60.

Van Valin, Robert D. (1999), Generalized semantic roles and the syntax-semantics interface, in: Francis Corblin/Carmen Dobrovie-Sorin/Jean-Marie Marandin (eds.), Empirical issues in formal syntax and semantics 2, The Hague, Thesus, 373-389.

Vázquez Rozas, Victoria (2006), Gustar-type verbs, in: J. Clancy Clements/Jiyoung Yoon (eds.), Functional approaches to Spanish syntax. Lexical semantics, discourse and transitivity, Basingstoke, Palgrave Macmillan, 80-114.
Commented [114]: Foris hatte seinen Verlagssitz doch in Dordrecht?

Commented [RW15R14]: Berlin/New York ist die richtige Ortsangabe.

Commented [RW16]: In dieser Publikation wird der Vorname als "J.", nicht "Joseph" angegeben. 